\title{
INFLUENCE OF SOIL MICROBIAL ACTIVITY AND PHYSICAL PROPERTIES ON SOIL RESPIRATION UNDER MAIZE (ZEA MAYS L.)
}

\author{
BoJARSZCZUK, J. * KSIĘŻAK, J. - GAŁĄZKA, A. - NIEDŹWIECKI, J. \\ Institute of Soil Science and Plant Cultivation, State Research Institute, Czartoryskich 8 Str., \\ 24-100 Puławy, Poland \\ (phone: +48-81-478-6796, fax: +48-81-478-6900) \\ *Corresponding author \\ e-mail: jolanta.bojarszczuk@iung.pulawy.pl \\ (Received 29 $9^{\text {th }}$ Dec 2018; accepted $8^{\text {th }}$ Apr 2019)
}

\begin{abstract}
Soil respiration is an important indicator of soil fertility and biological activity, which has impact on plant yield. The aim of the present study was the evaluation of soil respiration intensity depending on different soil treatment practices in cultivation of maize and to determine the effect of biology activity on soil respiration. The study was based on the long-term field experiment located at the Agricultural Experimental Station at the Institute of Soil Science and Plant Cultivation - State Research Institute in Grabów (Poland). Three objects were included in this research: maize cropped continuously (monoculture) with direct sowing, maize monoculture cropped continuously with full tillage and crop rotation (spring barley, winter wheat, maize) with full tillage. Research indicates that soil respiration depends on cultivation method used before the maize is sown. The analysis showed that soil respiration was correlated with its biological activity and biochemical parameters. The statistically strongest negative correlation was found between soil respiration and evapotranspiration, changes in carbon dioxide concentration and acid phosphatase activity, while strongest positive correlation was found between soil respiration and ammonifying bacteria. The simple regression analysis showed linear relationship between soil respiration and such parameters as: acid phosphatase activity and ammonifying bacteria.

Keywords: monoculture, tillage practice, microbial and biochemical properties, dehydrogenase activity, acid phosphatase, soil moisture

Abbreviations: Sr: soil respiration $\left(\mathrm{g} \mathrm{CO}_{2} \cdot \mathrm{m} \cdot \mathrm{h}^{-1}\right)$, E: evapotranspiration $\left(\mathrm{g} \mathrm{CO}_{2} \cdot \mathrm{m} \cdot \mathrm{h}^{-1}\right), \Delta \mathrm{CO}_{2}$ : changes in carbon dioxide concentration, $\triangle \mathrm{Mb}$ : changes in soil moisture, SM: soil moisture $(\%, \mathrm{v} / \mathrm{v})$, SBD: soil bulk density $\left(\mathrm{Mg} \cdot \mathrm{m}^{-3}\right)$, DHA: soil dehydrogenase activity DHA (ug formazan $\cdot \mathrm{g}$ DM of soil $\cdot 24 \mathrm{~h}^{-1}$ ), AcP: acid phosphatase (ug p-nitrophenol $\cdot \mathrm{g} \mathrm{DM}^{-1}$ of soil $\cdot \mathrm{h}^{-1}$ ), AlP: alkaline phosphatase (ug p-nitrophenol $\cdot \mathrm{g} \mathrm{DM}$ of soil $\left.\cdot h^{-1}\right), \mathrm{B}+\mathrm{A}$ : total bacteria and Actinomycetes number $\left(10^{7} \mathrm{CFU}\right.$ (colony forming units) $\mathrm{g} \mathrm{DM}^{-1}$ (dry matter) of soil, F: total fungi number $\left(10^{4} \mathrm{CFU} \cdot \mathrm{g} \mathrm{DM}^{-1}\right.$ of soil $), \mathrm{AM}$ : ammonifying bacteria $\left(10^{4} \mathrm{CFU} \cdot \mathrm{g}\right.$ $\mathrm{DM}^{-1}$ of soil), OLIGO: total oligotrophic bacteria $\left(10^{6} \mathrm{CFU} \cdot \mathrm{g} \mathrm{DM}^{-1}\right.$ of soil), KOP: total copiotrophic bacteria $\left(10^{6} \mathrm{CFU} \cdot \mathrm{g} \mathrm{DM}^{-1}\right.$ of soil $)$
\end{abstract}

\section{Introduction}

Soil respiration refers to the production of carbon dioxide by soil organisms (Luo and Zhou, 2006). A small part of soil respiration (below 10\%) results from the decomposition of resistant organic carbon particles (Hanson et al., 2000; Schlesinger and Andrews, 2000).

Soil capacity to produce $\mathrm{CO}_{2}$ varies depending on soil structure, season, intensity and quality of agrotechnical tillage, soil water, cultivated plant, fertilizer etc. (Moraru and Rusu, 2012). Soil respiration leads to $\mathrm{CO}_{2}$ emissions from soil to the atmosphere, in significant amounts for the global carbon cycle (Moraru et al., 2010).

Tillage practices influence soil physical, chemical and biological properties, which in turn may alter plant growth and yield (Czyż, 2011; Feiza et al., 2005; Gus et al., 2008; 
Mark and Al-Kaisi, 2004; Moroizumi and Horino, 2002; Natywa et al., 2009; Ozpinar and Cay, 2006; Rashidi and Keshavarzpour, 2009; Ulrich et al., 2006). They also have a significant influence on biological activities (Swędrzyńska et al., 2013; Ghimire et al., 2014) and soil $\mathrm{CO}_{2}$ efflux (Frank et al., 2006). The soil temperature and its moisture may be affected on soil respiration intensity (Box and Meentemeyer, 1993; Frank et al., 2006; Natywa et al., 2010).

Systems for soil gas measurements offer crucial information regarding production, consumption, and gas transportation, with major implications in quantitative and qualitative assessment of soil respiration and soil aeration (Moraru and Rusu, 2010).

Conventional tillage includes the largest number of soil treatment (Imadi et al., 2016). This method of soil cultivation allows a good aeration of the soil and increases its biological activity (Olesen et al., 2011).

Knowledge about the influence of soil microbial activity and physical properties on soil respiration is insufficient. This indicates a need to conduct research aimed at recognizing and understanding the responses of effect the microbial, biochemical and physical properties on soil efflux under various crop species.

The aim of the present study was evaluation of soil respiration intensity depending on different soil treatment practices and to determine the effect of biology activity on soil respiration.

\section{Materials and methods}

\section{Location of experiment}

The study was based on the long term field experiment located at the Agricultural Experimental Station (AES) of the Institute of Soil Science and Plant Cultivation - State Research Institute in Grabów (Mazowieckie voivodeship, Poland; 51 23 'N; 21 ${ }^{\circ} 38^{\prime} \mathrm{E}$ ). The experiment has been running since 2004. Experiment involving maize cropped continuously and rotated with other crops. The experimental scheme involved three following treatments:

1. Maize monoculture with direct seeding (zero tillage) (A)

2. Maize monoculture with full ploughing tillage (B)

3. Cultivation in crop rotation with full tillage (C)

Experiment was conducted on a grey brown podsolic soil formed from light loam (USDA soil classification) classified as very good rye complex. The ploughing layer of soil was characterized by low magnesium content, medium potassium content, and high phosphorus content. The size of a plot was $27.0 \mathrm{~m}^{2}$ at the set-up of the experiment and $21.0 \mathrm{~m}^{2}$ at harvest. The experiment was established using a long strip design in four replications.

Maize cultivar Delphine, sown at the end of April or at the beginning of May, with a precision seed drill. The fertilization dose of nitrogen amounted to $140 \mathrm{~kg} \mathrm{~N} \cdot \mathrm{ha}^{-1}$ $(70+70$ at the six-leaf stage). The doses of phosphorus and potassium for maize were $\mathrm{P}_{2} \mathrm{O}_{5}-80 \mathrm{~kg} \cdot \mathrm{ha}^{-1}$ and $\mathrm{K}_{2} \mathrm{O}-125 \mathrm{~kg} \cdot \mathrm{ha}^{-1}$. In the case of crop rotation, all plant species were grown. In all the years of the study, a full dose of manure was used for maize. It was cattle dung containing: $20-22 \%$ dry matter, $0.45-0.51 \% \mathrm{~N}, 0.12-0.17 \% \mathrm{P}, 0.53-$ $0.59 \%$.

$\mathrm{Cv}$. Antek of spring barley (sown at the first or second decade of April) and cv. Turnia of wheat were seeded. Annual fertilizer rates supplied to barley were $60 \mathrm{~N}, 35$ 
$\mathrm{P}_{2} \mathrm{O}_{5}$, and $50 \mathrm{~kg} \mathrm{ha}^{-1} \mathrm{~K}_{2} \mathrm{O}$, and to wheat $120 \mathrm{~N}, 40 \mathrm{P}_{2} \mathrm{O}_{5}$, and $70 \mathrm{~kg} \mathrm{ha}^{-1} \mathrm{~K}_{2} \mathrm{O}$. In order to measure the effects of maize tillage prior to the onset and after termination of the trial we assessed $\mathrm{pH}$ in $\mathrm{KCl}$ and soil contents (mg per $100 \mathrm{~g}$ of soil) of $\mathrm{P}_{2} \mathrm{O}_{5}$ (CFA method), $\mathrm{K}_{2} \mathrm{O}$ (FES method), MgO (AAS method), percentage of total nitrogen (CFA method). The results content yields of maize (plant height, weight of 1000 grains, parameters of maize cobs, plant density of harvest, grain yields of cereals) were published (Księżak et al., 2018).

\section{Soil respiration measurement}

Soil respiration ( $\mathrm{Sr}$ ) was measured twice by a model CIRAS-2 apparatus (PPSystems, USA), portable infrared $\mathrm{CO}_{2}$ analyzer equipped in Soil $\mathrm{CO}_{2}$ Flux dynamic closed Chamber. The closed chamber is having a head space volume of $1.17 \mathrm{dm}^{3}$, enclose an area of $75.6 \mathrm{~cm}^{2}$ and was kept inserted into the soil during the measurement. Soil respiration was estimated from the rate of increase in $\mathrm{CO}_{2}$ in the closed chamber during a 60 -s period. The measurements were conducted before sowing of maize (in term 15-25 of April depending on the year of the study) and after harvest (15-25 of October) in four replications. All measurement were done during day time (i.e. 9:0013:00 a.m.) on rows. Concentration value of carbon dioxide expressed in $\mathrm{g} \mathrm{CO}_{2} \cdot \mathrm{m}^{2} \cdot \mathrm{h}^{-1}$. The measurement range of SRC-1 is 0-9.99 $\mathrm{g} \mathrm{CO}_{2} \cdot \mathrm{m}^{2} \cdot \mathrm{h}^{-1}$. The level of evapotranspiration $(\mathrm{E})$, the differences in carbon dioxide concentration $\left(\Delta \mathrm{CO}_{2}\right)$, changes in soil moisture $\left(\Delta \mathrm{M}_{\mathrm{B}}\right)$ were also determined.

\section{Soil moisture measurement}

The soil moisture (SM, \%, v/v) and soil bulky density $\left(\mathrm{Mg} \cdot \mathrm{m}^{-3}\right)$ measurements were made on 7 depth level: $0-5,5-10,10-15,15-20,20-25,25-30$ and $30-35 \mathrm{~cm}$ in four replication for each variant of soil tillage, which made by made by weighing and drying method, using cylinders with a volume of $100 \mathrm{~cm}^{3}$. Soil for the determination of the physical properties was collected during the harvesting of maize for grain. For analysis used mean data of measurement from soil layer 0-30 cm and $30-35 \mathrm{~cm}$.

\section{Soil samples}

Soil samples were collected according to Polish Standard PN-ISO 1038-6 (1998). The soil samples in three replicates were taken from the $0-20 \mathrm{~cm}$ layer and sieved through a $2 \mathrm{~mm}$ sieve and stored in a refrigerator $\left(4^{\circ} \mathrm{C}\right)$ until analysis.

\section{Microbial and biochemical properties}

The soil samples were examined for different microorganisms groups. Microbial and biochemical properties analysis was described by Gałązka (2017).

\section{Statistical analysis}

Statistical analyses were performed using the Statistica Program PL (10.0). The analysis were carried out using ANOVA method in a proper model for the experimental design. The $95 \%$ confidence limit $(\mathrm{P}<0.05)$ was chosen to determine the significance of differences between soil respiration and studied parameters of soil chemical and biological properties. 
Course of weather conditions were different in the years of study. In Grabów, the total precipitation during the growing period was higher in the first and the second year of the study than the average multi-annual precipitation (by 40 and $33 \%$, respectively) (Table 1). In 2010, high precipitation occurred in August and September, while a rain deficit took place in June and July. In 2011, very abundant precipitation was recorded in July (3.5-fold higher than the multi-year average), while a shortage of rainfall occurred in June and August. The third year of the study (2012) was more favourable in terms of the quantity and distribution of precipitations. Same deficits were recorded in May and June (Table 1).

Table 1. Course of weather conditions during the vegetation periods. (Source: Bulletin of State Hydrological and Meteorological Service IMGW-PIB)

\begin{tabular}{|c|c|c|c|c|c|c|c|c|}
\hline \multirow{2}{*}{ Specification } & \multirow{2}{*}{ Year } & \multicolumn{6}{|c|}{ Month } & \multirow{2}{*}{ Sum } \\
\hline & & April & May & June & July & August & September & \\
\hline \multirow{3}{*}{ Rainfalls } & 2010 & 20.8 & 114.0 & 50.7 & 53.4 & 155.1 & 135.7 & 529.7 \\
\hline & 2011 & 35.9 & 74.5 & 52.4 & 298.8 & 35.6 & 3.6 & 500.8 \\
\hline & 2012 & 37.8 & 36.5 & 54.3 & 81.6 & 64.2 & 21.8 & 296.2 \\
\hline \multicolumn{2}{|c|}{ Rainfalls mean from multi-years (mm) } & 39.0 & 57.0 & 71.0 & 84.0 & 75.0 & $\mathbf{5 0 . 0}$ & 376.0 \\
\hline \multirow{3}{*}{ Temperature $\left({ }^{\circ} \mathrm{C}\right)$} & 2010 & 9.0 & 13.9 & 17.6 & 21.5 & 19.9 & 12.1 & 15.7 \\
\hline & 2011 & 10.3 & 13.9 & 18.5 & 18.4 & 18.8 & 14.7 & 15.8 \\
\hline & 2012 & 9.6 & 15.3 & 17.7 & 20.9 & 18.8 & 14.5 & 16.1 \\
\hline \multicolumn{2}{|c|}{ Temperature mean from multi-years $\left({ }^{\circ} \mathrm{C}\right)$} & 7.7 & 13.4 & 16.7 & 18.3 & 17.3 & 13.2 & 14.4 \\
\hline
\end{tabular}

Average from years 1871-2000

\section{Results and discussion}

Results of the study showed that the highest value of soil respiration, as before sowing as after harvest, was measured under maize cropped in monoculture with full ploughing tillage (C) (Fig. 1), while the least one, under maize cropped in the direct sowing system (A). Analysis of variance showed that treatments have significant effect on soil respiration (Fig. 1). So that, addition of soil simplification reduced $\mathrm{CO}_{2}$ emission while addition of soil tillage have influence on soil respiration. The research results obtained by Lamptey et al. (2017) showed that zero-tillage significantly decreased soil respiration compared to conventional tillage. Hryńczuk and Weber (2004) reported higher values of soil respiration in cultivation with full tillage compared to direct sowing. Kordas (2007) and Kordas and Zbroszczyk (2012) reported higher soil biological activity after soil treatment simplification and the least one in traditional cultivation. These authors found that as soil is more simplificated, as biological activity and ability of soil respiration are higher. Analysis showed that higher soil respiration in all cultivation method was recorded after harvest of maize (second term). The differences between terms amounted $25 \%$. Analysis of variance showed that the mean $\mathrm{CO}_{2}$ emission was significantly influenced by seasons. In the studies by Amos et al. (2005), Lou et al. (2004) and Natywa et al. (2010), the strongest soil respiration activity was at springtime. Wielgosz and Szember (2006) noted a decline in soil respiration in the summer. Amos et al. (2005) and Lou et al. (2004) attributed this result to the increased root respiration as well as to the soil temperature and moisture conditions. Quemada (2001) reported that soil respiration was greatly affected by temperature and 
water content. In his study the highest values were obtained in August when high temperatures and water content produced the highest respiration. These results were confirmed also by Frank et al. (2002), Bajracharya et al. (2000) and Mielnick and Dugas (2000). According to Sandor et al. (2011) beginning of summer could also offer good conditions for development of soil microbial biomass which in turn could reach the highest metabolic activity. As Lou et al. (2004) reported high soil temperature is positively correlated with $\mathrm{CO}_{2}$ flux.

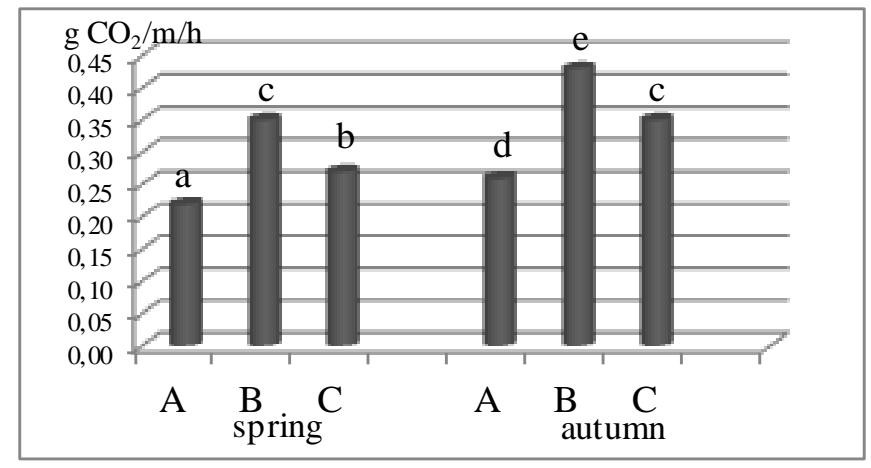

Figure 1. Soil respiration (Sr) depending on method of soil cultivation (average of the years of the study). Values followed by a different letter are significantly different $(P<0.05)$

The evapotranspiration process was most strongly under maize cropped in monoculture in full tillage, but strongly the least under maize cropped in crop rotation. Significantly higher levels of this parameter were found in date after sowing (Fig. 2). The difference between two terms regardless soil tillage amounted to $81 \%$.

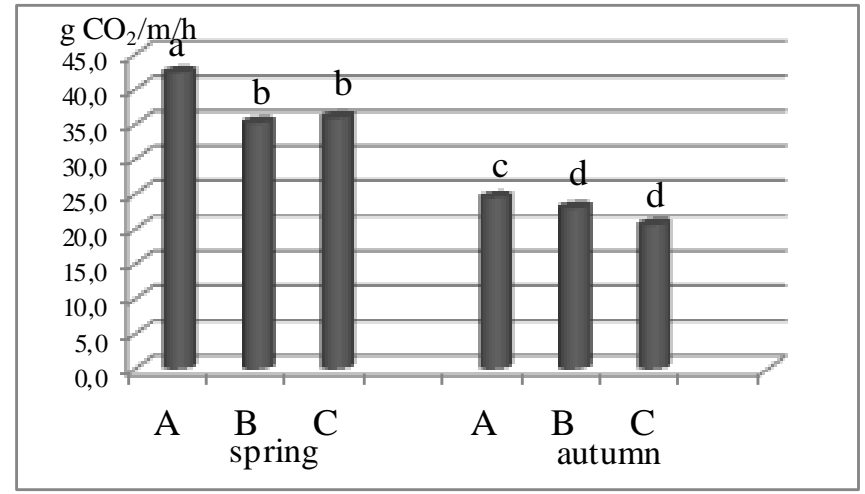

Figure 2. Evapotranspiration (Sr) depending on method of soil cultivation (average of the years of the study). Values followed by a different letter are significantly different $(P<0.05)$

The differences in carbon dioxide concentration were highest in term after maize sowing. Compared method of soil cultivation, the highest changes in this parameter in both terms were found under maize cropped in monoculture (Fig. 3). While the least changes in the changes dioxide concentration were differentiated depend on season. In the first term the least value of this parameter were found under maize cropped in monoculture in full tillage, while in the second term in crop rotation. 


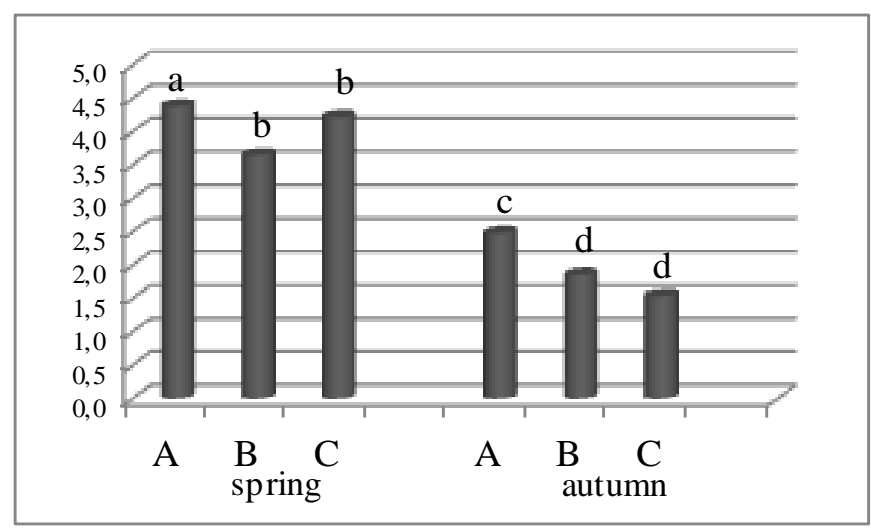

Figure 3. Changes in carbon dioxide concentration depending on method of soil cultivation $\left(\mathrm{CCO}_{2}\right)$. Values followed by a different letter are significantly different $(P<0.05)$

The highest changes in soil moisture were recorded under maize cropped in direct sowing, while the smallest one in crop rotation (Fig. 4). A significant variability was recorded in the changes in soil moisture between method of soil cultivation. In the studies of Lamptey et al. (2017) soil water content increased under no-tillage soils compared with conventional treatment. According to Cook and Orchad (2008) to compare the effect on respiration, a measure of the soil-water status is required.

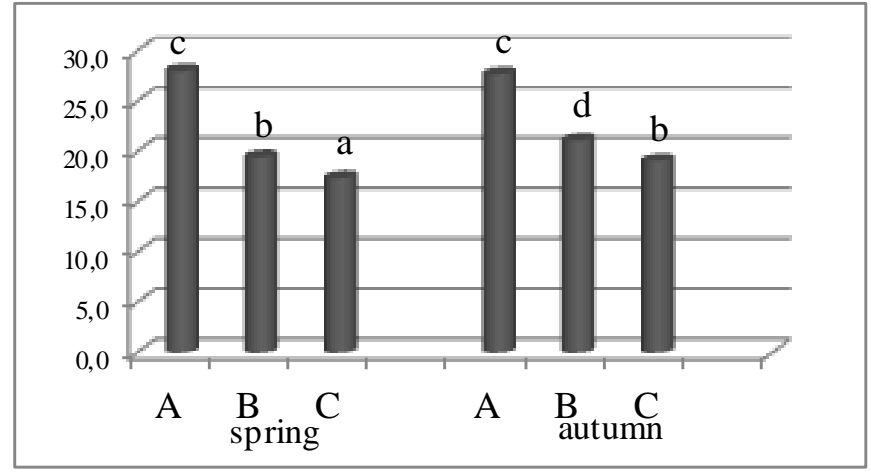

Figure 4. Changes in soil moisture $(\triangle M B)$ depending on method of soil cultivation. Values followed by a different letter are significantly different $(P<0.05)$

The soil respiration was correlated with its biological activity and biochemical parameters (Table 2). The statistically strongest negative correlation was found between soil respiration and evapotranspiration (-0.495), changes in carbon dioxide concentration (-0.493) and acid phosphatase activity (-0.683), while strongest positive correlation was found between soil respiration and ammonifying bacteria (0.598).

Statistical analysis revealed also that no linear relationship was found between soil respiration and such parameters as: evapotranspiration and changes in carbon dioxide concentration (Fig. 5a, b) and biochemical parameters as: soil dehydrogenase activity and acid phosphatase activity (Figs. 6 and 7). According to Cook and Orchad (2008) to compare the effect on respiration, a measure of the soil-water status is required. 
Dehydrogenase and phosphatase activities are good indicators of changes of soil parameters and widely used microbial parameters of soil biology (Wolińska et al., 2013). Phosphatase can be a good indicator of the mineralization potential of organic phosphorus and soil biological activity. In the studies of Gałązka et al. (2017) the dehydrogenase activity was is in correlation with the increased number of the most examined groups of microorganisms.

Table 2. The Pearson's correlation coefficient of soil respiration and selected microbiological, chemical and biochemical parameters

\begin{tabular}{c|c|c|c|c|c|c|c|c}
\hline Parameter & $\mathbf{S r}$ & $\mathbf{E}$ & $\mathbf{A C O}_{\mathbf{2}}$ & $\mathbf{\Delta M b}$ & $\mathbf{S M}_{\mathbf{1}}$ & $\mathbf{S B D}_{\mathbf{1}}$ & $\mathbf{S M}_{\mathbf{2}}$ & $\mathbf{S B D}_{\mathbf{2}}$ \\
\hline $\mathbf{S r}$ & - & $\mathbf{- 0 . 4 9 5}$ & $\mathbf{- 0 . 4 9 3}$ & -0.141 & 0.242 & -0.085 & -0.174 & 0.164 \\
$\mathbf{E}$ & $\mathbf{- 0 . 4 9 5}$ & - & $\mathbf{0 . 7 8 8}$ & 0.175 & 0.111 & -0.010 & 0.100 & -0.028 \\
$\mathbf{\Delta C \mathbf { O } _ { 2 }}$ & $\mathbf{- 0 . 4 9 3}$ & $\mathbf{0 . 7 8 8}$ & - & 0.051 & 0.236 & -0.029 & 0.237 & -0.158 \\
$\mathbf{\Delta M b}$ & -0.141 & 0.175 & 0.051 & - & -0.004 & 0.096 & 0.003 & -0.004 \\
$\mathbf{S M}_{\mathbf{1}}$ & 0.242 & 0.111 & 0.236 & -0.004 & - & - & - & - \\
$\mathbf{S B D}_{\mathbf{1}}$ & -0.085 & -0.010 & -0.029 & 0.096 & - & - & - & - \\
$\mathbf{S M}_{\mathbf{2}}$ & -0.174 & 0.100 & 0.237 & 0.003 & - & - & - & - \\
$\mathbf{S B D}_{2}$ & 0.164 & -0.028 & -0.158 & -0.004 & - & - & - & - \\
$\mathbf{D E H}$ & -0.348 & -0.189 & -0.323 & 0.422 & -0.086 & 0.177 & -0.208 & 0.077 \\
$\mathbf{A c P}$ & $\mathbf{- 0 . 6 8 4}$ & 0.383 & 0.237 & $\mathbf{0 . 5 4 2}$ & 0.266 & 0.273 & 0.150 & -0.105 \\
$\mathbf{A l P}$ & 0.182 & 0.353 & 0.302 & -0.029 & 0.192 & 0.101 & 0.186 & -0.320 \\
$\mathbf{B}+\mathbf{A}$ & 0.264 & $\mathbf{- 0 . 6 2 4}$ & $\mathbf{- 0 . 6 6 7}$ & 0.000 & -0.120 & 0.235 & -0.142 & -0.208 \\
$\mathbf{F}$ & 0.027 & -0.237 & -0.336 & 0.320 & $\mathbf{- 0 . 3 5 4}$ & 0.384 & -0.440 & 0.036 \\
$\mathbf{A M}$ & $\mathbf{0 . 5 9 8}$ & $\mathbf{- 0 . 6 1 2}$ & $\mathbf{- 0 . 5 8 7}$ & 0.040 & -0.233 & 0.104 & -0.177 & -0.160 \\
OLIGO & 0.274 & -0.383 & $\mathbf{- 0 . 4 7 7}$ & 0.083 & $\mathbf{- 0 . 4 8 6}$ & 0.085 & -0.451 & -0.040 \\
KOP & -0.013 & -0.375 & $\mathbf{- 0 . 5 3 4}$ & 0.324 & $\mathbf{- 0 . 4 8 3}$ & $\mathbf{0 . 4 5 9}$ & $\mathbf{- 0 . 5 5 6}$ & 0.043 \\
\hline
\end{tabular}

Values in bold are statistically significant $(\mathrm{P} \leq 0.05)$

Sr: soil respiration $\left(\mathrm{g} \mathrm{CO}_{2} \cdot \mathrm{m} \cdot \mathrm{h}^{-1}\right)$, E: evapotranspiration $\left(\mathrm{g} \mathrm{CO}_{2} \cdot \mathrm{m} \cdot \mathrm{h}^{-1}\right), \Delta \mathrm{CO}_{2}$ : changes in carbon dioxide concentration, $\Delta \mathrm{Mb}$ : changes in soil moisture, $\mathrm{SM}_{1}$ : soil moisture in $0-30 \mathrm{~cm}$ soil layer $(\%, \mathrm{v} / \mathrm{v})$, $\mathrm{SBD}_{1}$ : soil bulk density in $0-30 \mathrm{~cm}$ soil layer $\left(\mathrm{Mg} \cdot \mathrm{m}^{-3}\right), \mathrm{SM}_{2}$ : soil moisture in $30-35 \mathrm{~cm}$ soil layer $(\%$, $\mathrm{v} / \mathrm{v}), \mathrm{SBD}_{2}$ : soil bulk density in 30-35 $\mathrm{cm}$ soil layer $\left(\mathrm{Mg} \cdot \mathrm{m}^{-3}\right)$, (DHA: soil dehydrogenase activity DHA (ug formazan $\cdot \mathrm{g} \mathrm{DM}$ of soil $\cdot 24 \mathrm{~h}^{-1}$ ), AcP: acid phosphatase (ug p-nitrophenol $\cdot \mathrm{g} \mathrm{DM}^{-1}$ of soil $\cdot \mathrm{h}^{-1}$ ), AlP: alkaline phosphatase (ug p-nitrophenol $\cdot \mathrm{g}$ DM of soil $\cdot \mathrm{h}^{-1}$ ), B $+\mathrm{A}$ : total bacteria and Actinomycetes number $\left(10^{7}\right)$, CFU: colony forming units, $\mathrm{g} \mathrm{DM}^{-1}$ : dry matter of soil, $\mathrm{F}$ : total fungi number $\left(10^{4} \mathrm{CFU} \cdot \mathrm{g}\right.$ $\mathrm{DM}^{-1}$ of soil), AM: ammonifying bacteria $\left(10^{4} \mathrm{CFU} \cdot \mathrm{g} \mathrm{DM}^{-1}\right.$ of soil), OLIGO: total oligotrophic bacteria $\left(10^{6} \mathrm{CFU} \cdot \mathrm{g} \mathrm{DM}^{-1}\right.$ of soil), KOP: total copiotrophic bacteria $\left(10^{6} \mathrm{CFU} \cdot \mathrm{g} \mathrm{DM}^{-1}\right.$ of soil)

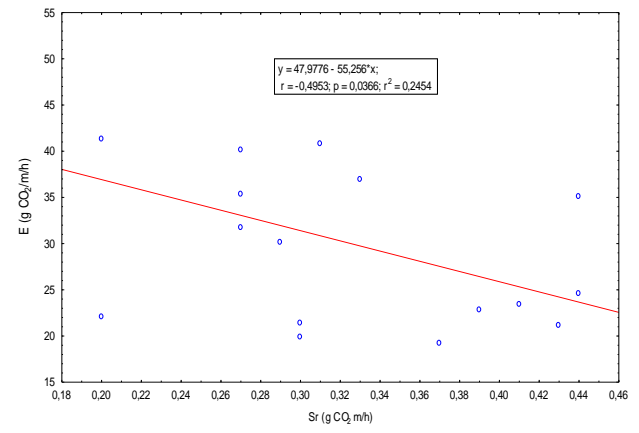

a

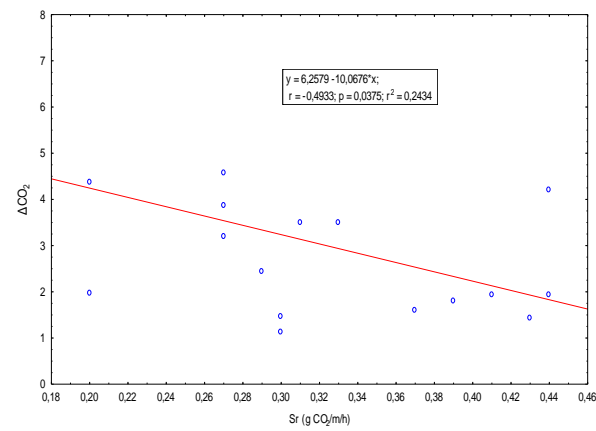

b

Figure 5. Relationship between soil respiration $(S r)$ and (a) evapotranspiration (E), and (b) changes in carbon dioxide concentration soil moisture $\left(\triangle \mathrm{CO}_{2}\right)$ 


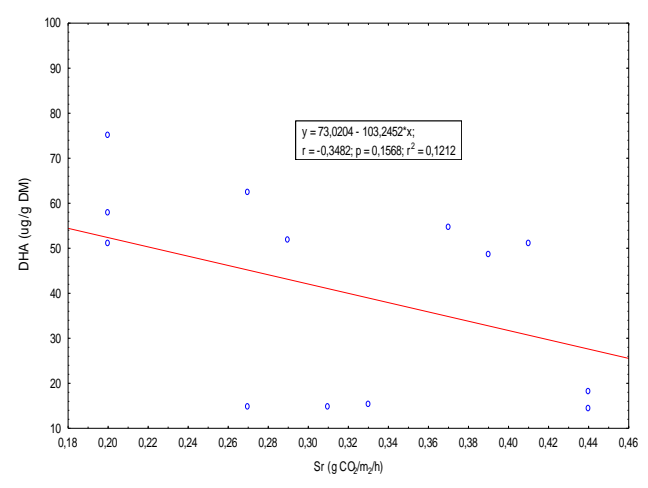

Figure 6. Relationship between soil respiration $(\mathrm{Sr})$ and soil dehydrogenase activity (DHA)

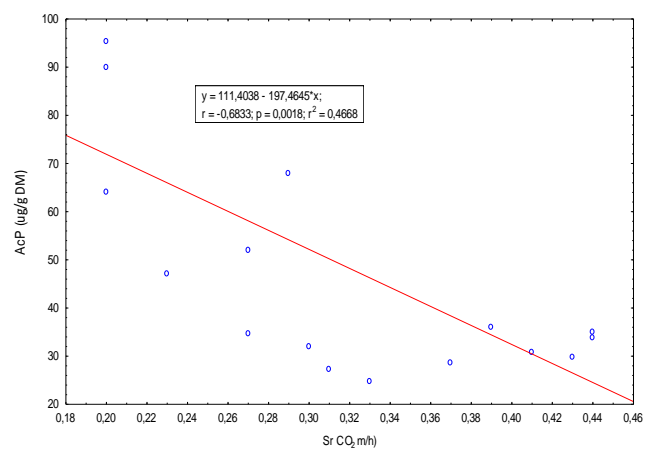

Figure 7. Relationship between soil respiration ( $\mathrm{Sr}$ ) and acid phosphatase (AcP)

Soil respiration was not significantly affected by the soil moisture and soil bulk density in 0-30 $\mathrm{cm}$ soil layer (Table 2). The simple regression analysis showed linear relationship between soil respiration and such parameters as: acid phosphatase activity and ammonifying bacteria (Figs. 7 and 8). The strongest relationships was found between soil respiration and acid phosphatase activity, which is confirm by value of coefficient of determination $\left(\mathrm{R}^{2}=47 \%\right)$.

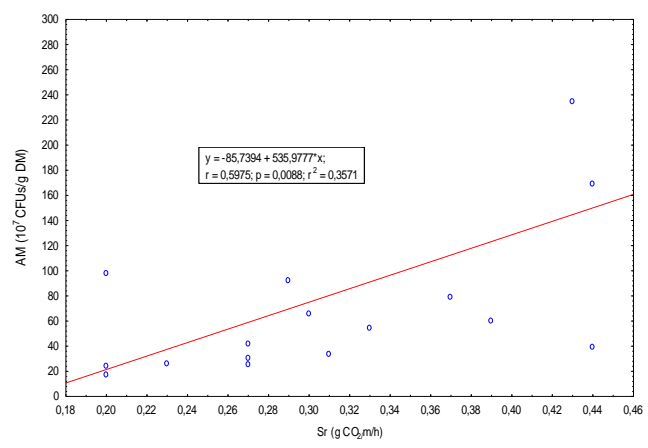

Figure 8. Relationship between soil respiration (Sr) and ammonifying bacteria (AM)

The available literature lacks studies on the effect of physical properties on soil respiration. Małecka et al. (2012) found that the no-tillage systems favoured the increase of soil moisture and density, as well as the reduction of capillary water 
capacity, especially in the 0-10 cm layer. The studies of Morris et al. (2010) and Raczkowski et al. (2012) indicate the increase in the volume density of soils in the ploughed systems. In own studies, analysis showed that soil bulk density in 0-30 cm soil layer $\left(\mathrm{SBD}_{1}\right)$ was significantly affected total copiotrophic bacteria (KOP) (0.459), while soil bulk density in deeper layer $(30-35 \mathrm{~cm})$ was not affected any characteristics. Soil moisture in both deep soil layer: $0-30 \mathrm{~cm}$ and $30-35 \mathrm{~cm}\left(\mathrm{SM}_{1}\right.$ and $\left.\mathrm{SM}_{2}\right)$ was negatively influence on total copiotrophic bacteria (KOP) (-0.483 and -0.556 respectively). Soil moisture in $0-30 \mathrm{~cm}$ layer was negatively significantly influence on total fungi number (F) (-0.354) and total oligotrophic bacteria (OLIGO) (-0.486) (Tab. 2).

The continuous use of the no-tillage system with crop rotation usually results in an increase of the microbial biomass and decrease in soil respiration, therefore, displaying evident long-term effects on the increase of soil C contents (Valpassos et al., 2001).

Soil respiration refers to microbial decomposition of dead plant residues and soil organic matter (Kuzyakov and Gavrichkova, 2010), which is controlled by soil microbial activities and soil C content. According to Lou et al. (2011) soil microbial activities are influenced by soil physicochemical conditions, such as soil moisture.

Soil moisture was considered by Bonal et al. (2008); Luo and Zhou (2006) and Lou et al. (2011) to be the secondary important factor controlling soil respiration. According to Huang et al. (2014) soil respiration was negatively correlated with soil moisture at high soil moisture content (> 19). According to Zhang et al. (2016) soil respiration was negatively correlated with soil moisture and soil pH. While Chang et al. (2016) reported that soil respiration is mainly controlled by soil temperature and moisture. According to Pietri and Brookers (2009) soil $\mathrm{pH}$ also had been proved to be an important factor influencing microbial respiration. The results of Șandor and Opruța (2012) show a relationship between soil moisture and soil respiration. It was suggested (Mielnick and Dugas, 2000) that wet soil at deep depth may counteract the effect of surface dry soil on soil respiration.

\section{Conclusions}

The results of soil samples analysis (soil properties and microbial activity) would not provide a complete understanding of the relation between soil properties and soil respiration. However, the values may be used as indicators of changes on soil quality, and parameters such as respiration are sensitive indices to study the effect of crop systems in the soil microbiological environment. Among the studied soil treatments, zero-tillage system exhibited better results for bulk density, soil chemical properties. Our study did not present enough variety to go further in our conclusions, but it confirms the relevance of influence effects between factors.

This study demonstrated that tillage systems under maize influence soil respiration along with soil biochemical, physical and other microbiological properties. Further research is needed to determine the soil respiration in long-time period of field experiment under maize growth in different agricultural management practices.

Acknowledgements. This research did not receive any specific grant from funding agencies in the public, commercial, or not-for-profit sectors. 


\section{REFERENCES}

[1] Amos, B., Arkebauer, T. J., Doran, J. W. (2005): Soil surface greenhouse gases in an irrigated maize-bazed agroecosystem. - Soil Science Society of America Journal 69: 387395.

[2] Bajracharya, R. M., Lal, R., Kimble, J. M. (2000): Diurnal and seasonal $\mathrm{CO}_{2}-\mathrm{C}$ flux from soil as related to erosion phases in central Ohio. - Soil Science Society of America Journal 64: 286-293.

[3] Bonal, D., Bosc, A., Ponton, S., Goret, J. Y., Burban, B., Gross, P., Bonnefond, J. M., Elbers, J. A. N., Longdoz, B., Epron, D. (2008): Impact of severe dry season on net ecosystem exchange in the neotropical rainforest of French Guiana. - Global Change Biology 14: 1917-1933.

[4] Box, E. O., Meentemeyer, V. (1993): Soil carbon dioxide evolution: environmental controls, world patterns and amounts. - Conference Papers 18 "Geography of organic matter production and decay". IGiPZ PAN, Warszwa, pp. 21-49.

[5] Chang, S. X., Shi, Z., Thomas, R. R. (2016): Soil respiration and its temperature sensitivity in agricultural and afforested poplar plantation systems in northern Alberta. Biology and Fertility of Soils 52: 629-641.

[6] Cook, F. J., Orchad, V. A. (2008): Relationships between soil respiration and soil moisture - Soil Biology and Biochemistry 40: 1013-1018.

[7] Czyż, E. (2011): Effects of cultivation of maize (Zea mays L.) in monoculture and crop rotation on some soil physical properties. - Roczniki Gleboznawcze 62(1): 12-24.

[8] Feiza, V., Irena, D., Danute, S. (2005): Soil Physical and Agrochemical Properties Changes, Weediness and Yield of Crops in Long-Term Tillage Experiment in Lithuania. - Scientific Publication Vol. 48. Agronomy, USAMV, Iasi.

[9] Frank, A. B., Liebig, M. A., Hanson, J. D. (2002): Soil carbon dioxide fluxes in northern semiarid grasslands. - Soil Biology and Biochemistry 34: 1235-1241.

[10] Frank, A. B., Liebig, M. A., Tanaka, D. L. (2006): Management effects on soil $\mathrm{CO}_{2}$ efflux in northern semiarid grassland and cropland. - Soil \& Tillage Research 89: 78-85. DOI: 10.1016/j.still.2005.06.009. www.sciencedirect.com.

[11] Gałązka, A., Gawryjołek, K., Perzyński, A., Gałązka, R., Księżak, J. (2017): Changes in enzymatic activities and microbial communities in soil under long-term maize monoculture and crop rotation. - Polish Journal of Environmental Studies 26: 39-46.

[12] Ghimire, R., Norton, J. B., Stahl, P. D., Norton, U. (2014): Soil microbial substrate properties and microbial community responses under irrigated organic and reduced-tillage crop and forage production systems. - PLoS ONE 9: e103901.

[13] Gus, P., Rusu, T., Bogdan, I. (2008): Factors which impose completing preserving effects of minimum soil tillage systems on arable fields situated on slopes. - 5th International Symposium-Soil Minimum Tillage System, Risoprint, Cluj-Napoca 1: 155-161.

[14] Hanson, P. J., Edwards, N. T., Garten, C. T., Andrews, J. A. (2000): Separating root and soil microbial contributions to soil respiration: a review of methods and observations. Biogeochemistry 48: 115-146. https://doi.org/10.1023/A:1006244819642.

[15] Hryńczuk, B., Weber, R. (2004): Impact of tillage on the intensity of microbial transformation in soil and plant yield. - Annales UMCS, Sectio E, Agriculture 59(2): 639-648.

[16] Huang, Z., Yu, Z., Wang, M. (2014): Environmental controls and the influence of tree species on temporal variation in soil respiration in subtropical China. - Plant and Soil 382: 75-87.

[17] Imadi, S. R., Shazadi, K., Gul, A., Hakeem, K. R. (2016): Sustainable Crop Production System. - In: Hakeem, K., Akhtar, M., Abdullah, S. (eds.) Plant, Soil and Microbes. Springer, Cham.

[18] Kordas, L. (2007): Wpływ sposobu uprawy roli i nawożenia azotowego na respirację gleby. - Zeszyty Naukowe UP Wrocław, Inżynieria Rolnicza 552: 6: 65-71. 
[19] Kordas, L., Zbroszczyk, U. (2012): Wpływ systemu uprawy roli i efektywnych mikroorganizmów (EM) na właściwości biologiczne gleby spod pszenicy jarej uprawianej w krótkotrwałej monokulturze. - Fragmenta Agronomica 29(3): 95-102.

[20] Księżak, J., Bojarszczuk, J., Staniak, M. (2018): Comparison of maize yield and soil chemical properties under maize (Zea mays L.) grown in monoculture and crop rotation. Journal of Elementology 23(2): 531-543. DOI: 10.5601/jelem.2017.22.3.1453.

[21] Kuzyakov, Y., Gavrichkova, O. (2010): REVIEW: Time lag between photosynthesis and carbon dioxide efflux from soil: a review of mechanisms and controls. - Global Change Biology 16: 3386-3406.

[22] Lamptey, S., Li, L., Xie, J., Zhang, R., Luo, Z., Cai, L., Liu, J. (2017): Soil respiration and net ecosystem production under different tillage practices in semi-arid Northwest China. - Plant Soil Environment 63(1): 14-21.

[23] Luo, Y., Zhou, X. (2006): Soil Respiration and the Environment. - Academic Press, San Diego. doi.org/10.1016/B978-0-12-088782-8.X5000-1.

[24] Lou, Y., Li, Z., Zhang, T., Liang, Y. (2004): $\mathrm{CO}_{2}$ emissions from subtropical arable soils of China. - Soil Biology \& Biochemistry 36: 1835-1842.

[25] Lou, Y. L., Liang, W. J., Xu, M. G., He, X. H., Wang, Y. D., Zhao, K. (2011): Straw coverage alleviates seasonal variability of the topsoil microbial biomass and activity. Catena 86: 117-120.

[26] Małecka, I., Swędrzyńska, D., Blecharczyk, A., Dytman-Hagedorn, M. (2012): Impact of tillage systems for pea production on physical, chemical and microbiological soil properties. - Fragmenta Agronomica 29(4): 106-116.

[27] Mark, A. L., Al-Kaisi, M. (2004): Strip-tillage effect seedbed soil temperature and other soil physical properties. - Soil and Tillage Research 8(1-2): 233-249.

[28] Mielnick, P. C., Dugas, W. A. (2000): Soil $\mathrm{CO}_{2}$ flux in a tallgrass prairie. - Soil Biology \& Biochemistry 32: 221-228.

[29] Moraru, P. I., Rusu, T. (2012): Effect of tillage systems on soil moisture, soil temperature, soil respiration and production of wheat, maize and soybean crops. - Journal of Food, Agriculture and Environment 10(2): 445-448.

[30] Moraru, P. I, Rusu, T., Sopterean, M. L. (2010): Soil tillage conservation and its effect on erosion control, water management and carbon sequestration. - In ProEnvironment ProMediu no. 3(6).

[31] Moroizumi, T., Horino, H. (2002): The effects of tillage on soil temperature and soil water. - Soil Science 167(8): 548-559.

[32] Morris, N. L., Miller, P. C. H., Orson, J. H., Froud-Williams, R. J. (2010): The adoption of non-inversion tillage systems in the United Kingdom and the agronomic impact on soil, crops and the environment. A review. - Soil Tillage Research 108: 1-15.

[33] Natywa, M., Majchrzak, L., Sawicka, A. (2009): Effect of soil tillage system on the enzymatic activity in soil and maize yield. - Ekologia i Technika 17(4): 171-177.

[34] Natywa, M., Ambroży, K., Sawicka, A., Wolna-Maruwka, A. (2010): Aktywność respiracyjna i dehydrogenazowa gleby pod uprawą kukurydzy w zależności od różnych dawek nawozu azotowego. - Nauka Przyroda Technologie, Rolnictwo 4(6): \#89.

[35] Olesen, J. E., Trnka, M., Kersebaum, K. C., Skjelvåg, A. O., Seguin, B., Peltonen- Sainio, P., Rossi, F., Kozyra, J., Micale, F. (2011): Impacts and adaptation of European crop production systems to climate change. - European Journal of Agronomy 34: 96-112.

[36] Ozpinar, S., Cay, A. (2006): Effect of different tillage systems on the quality and crop productivity of a clay-loam soil in semi-arid north-western Turkey. - Soil Tillage Research 88(1-2): 95-106.

[37] Pietri, J. A., Brookes, P. (2009): Substrate inputs and pH as factors controlling microbial biomass, activity and community structure in an arable soil. - Soil Biology \& Biochemistry 41: 1396-1405. 
[38] Polish Standard (1998): PN-ISO 10381-6 Quality of Soil. - Collected samples. Principles of collected and kept of soil samples to the microbiological research in laboratory conditions.

[39] Quemada, M. (2001): Soil respiration 1 year after sewage sludge application. - Biology of Fertility of Soils 33: 344-346.

[40] Raczkowski, C. W., Mueller, J. P., Busscher, W. J., Bell, M. C., McGraw, M. L. (2012): Soil physical properties of agricultural systems in a large-scale study. - Soil Tillage Research 119: 50-59.

[41] Rashidi, M., Keshavarzpour, F. (2009): Effect of different tillage methods on grain yield and yield components of maize (Zea mays L.). - International Journal of Agriculture and Biology 9(2): 274-277.

[42] Sandor, M., Opruța, C. (2012): The effects of mineral and organic fertilizers on soil respiration in a potato field. - Bulletin UASVM Agriculture 69(2): 122-127.

[43] Șandor, M., Brad, T., Maxim, C., Toader, C. (2011): The influence of selected meteorological factors on microbial biomass and mineralization of two organic fertilizers. - Notulae Botanicae Horti Agrobotanici Cluj Napoca 39: 107-113.

[44] Schlesinger, H. W., Andrews, J. A. (2000): Soil respiration and the global carbon cycle. Biogeochemistry 48: 7-20. https://doi.org/10.1023/A:1006247623877.

[45] Swędrzyńska, D., Małecka, I., Blecharczyk, A., Swędrzyński, A., Starzyk, J. (2013): Effects of various long-term tillage system on some chemical and biological properties in soil. - Polish Journal of Environmental Studies 22(6): 1835-1844.

[46] Ulrich, S., Hofmann, B., Tischer, S., Christen, O. (2006): Influence of Tillage on Soil Quality in a Long-Term Trial in Germany. - In: Horn, R. et al. (eds.) Soil Management for Sustainability. IUSS, Catena Verlag, Reiskirchen, pp. 110-116.

[47] Valpassos, M. A. R., Cavalcante, E. G. S., Cassiolato, A. M. R, Alves, M. C. (2001): Effects of soil management systems on soil microbial activity, bulk density and chemical properties. - Pesquisa Agropecuária Brasileira 36(12): 1539-1545.

[48] Wielgosz, E., Szember, A. (2006): Wpływ wybranych roślin na liczebność i aktywność drobnoustrojów glebowych. - Annales UMCS, Sectio E 61: 107-119.

[49] Wolińska, A., Stepniewska, Z., Szymańska, E. (2013): Dehydrogenase activity of soil microorganisms and the total DNA level in soil of different use. - Journal of Agricultural Science and Technology B3: 613-622.

[50] Zhang, Y., Yan, Y., Fu, X., Yang, J., Zhang, S., Xu, S., Tang, Z., Li, Z., Lu, S. (2016): Responses of soil microbial respiration to plantations depend on soil properties in subtropical China. - Journal of Integrative Agriculture 15(6): 1376-1384. 